\title{
ENTRE A FRONTEIRA E O LIMIAR: O AUTOR E O NARRADOR EM SCENAS DA VIDA AMAZÔNICA
}

\author{
Aline Costa da Silva ${ }^{1}$
}

\begin{abstract}
RESUMO
A história da literatura foi marcada pela seleção de determinadas obras e autores para composição do cânone. Outras figuram às margens, recuperadas, entretanto, pelo leitor que a atualiza e a discute. Scenas da Vida Amazônica é uma dessas obras, cuja recepção não apenas a retoma como coloca em debate questionamentos acerca da constituição da obra, ora compreendida como um texto de cunho etnográfico, ora como literário. Embasado na primeira edição da obra (1886), este artigo busca discutir sobre o estatuto que a configura, a partir dos construtos teóricos de Walter Benjamim (1994) acerca da ideia de limiar e sua relação com a ficcionalidade, relacionado ao pensamento de Wolf Schimid (2010) referente ao evento como condição imprescindível à narratibilidade. Ainda, considera os estudos de Harold Bloom (1995), Gérard Genette (2008), Wolfgang Iser (1983) e Josefine Ludmer (2007). Como resultado, compreende-se o limiar como lugar de excelência do narrador e marca indelével da ficção, a qual assim se constitui e se afirma a partir de um dado evento. Tanto nas narrativas quanto nas descrições, entre os capítulos e, ainda, da literatura em relação às demais produções de José Veríssimo, Scenas da Vida Amazônica é uma obra circunscrita por passagens.
\end{abstract}

Palavras-chave: José Veríssimo. Scenas da Vida Amazônica. Fronteira. Limiar. Eventualidade.

\begin{abstract}
The history of literature was marked by the selection of certain works and authors for the composition of the canon. Others remain on the sidelines, recovered, however, by the reader that who updates and discusses it. Scenas da Vida Amazônica is one of these works, whose reception not only retakes it, but also raises issues about the constitution of the work, which is understood both as an ethnographic text and as a literary one. Based on the first edition of the work (1886), this article aims to discuss the statute that stablishes it, following the theoretical constructs of Walter Benjamim (1994) about the idea of threshold and its relation with fictionality and associating it to the thought of Wolf Schimid (2010) that regards event as an essential condition of narrativity. Furthermore, it considers the studies of Harold Bloom (1995), Gérard Genette (2008), Wolfgang Iser (1983) and Josefine Ludmer (2007). As a result, threshold is understood as the narrator's point of excellence and as an indelible mark of fiction, which constitutes and afirms itself from a certain event. Within the narratives and descriptions, among the chapters and beyond, relating literature to other productions of José Veríssimo, Scenas da Vida Amazônica is a work circumscribed by passages.
\end{abstract}

Keywords: José Veríssimo. Scenas da Vida Amazônica. Boundary. Limiar. Eventuality.

Recebido em: 10/08/2017 Aprovado em: 04/09/2017

\footnotetext{
${ }^{1}$.Doutoranda em Estudos Literários pelo Programa de Pós- Graduação em Letras- PPGL/UFPA. Email: alineclau_cs@yahoo.com.br.
} 


\section{INTRODUÇÃO}

Na História Literária há diversas discussões acerca do caráter de uma obra, seu estatuto, crítica e inserção no cânone que pode ou não consagrá-la. As razões para tais consagrações são várias, incluindo questões que ultrapassam os critérios literários. Conforme afirma Harold Bloom (1995, p.23), a canonização de uma obra se dá a partir da "escolha de livros em nossas instituições de ensino", a qual não ocorre senão em seleções que se configuram a partir ideologias de gênero, raça, origem geográfica e classe social, a partir das quais muitas obras e autores tornam-se ausentes, ou melhor, excluídos, embora tenham valores e qualidades literárias certificadas.

Estas questões nortearam estudo recente ${ }^{2}$ sobre a recepção da obra de José Veríssimo de Dias Matos, especificamente Scenas da Vida Amazônica, dado o seu valor para o entendimento da evolução intelectual do crítico, bem como para repensar a historiografia literária brasileira e questionar a imutabilidade do cânone, no qual se encontra apartada toda obra que não seja partícipe do que Pierre Bourdieu (1982) denomina "grupo dominante".

Tratando-se da obra, Scenas da Vida Amazônica (1886) ${ }^{3}$, de José Veríssimo, a única de sua produção no campo da literatura é, portanto, basilar para a compreensão de como o crítico Veríssimo pensou as questões literárias e extraliterárias de nossa literatura e sua relação com a história, reforçando-se, aqui, a inquietação em torno das perspectivas e convergências entre o ficto e o facto na obra. Chamou atenção, na pesquisa, o atual campo interdisciplinar de sua circulação e a parca recepção no contexto de suas primeiras publicações.

Ficou, no entanto, a se responder mais atentamente acerca da constituição de Scenas, bem como dos textos informativos sobre ela, uma vez que as tipologias textuais presentes na obra ora se separam, delimitando os textos e ora se retomam, ainda que no nível das ideias e a título de exemplificação nos contos e esbocetos, levando os leitores a diferentes interpretações

\footnotetext{
${ }^{2}$ Dissertação de mestrado defendida pelo Programa de Pós-Graduação em Linguagens e Saberes da AmazôniaPPLSA/UFPA.

${ }^{3}$ Antes da publicação do livro, o autor, José Veríssimo, realizou uma série de outros escritos que compreendiam estudos literários e etnográficos. Dentre eles, em 1888, Primeiras páginas, e nele Quadros Paraenses, no qual foram primeiramente lançados os Esbocetos que serão posteriormente explicitados.

Em 1883 e 1884, frente à Revista Amazônica, publicou os artigos —'Íldolos Amazônicos", _"A Linguagem Popular Amazônica", _-"cenas da Vida Amazônica- O Boto", _-'Tradições, crenças e superstições amazônicas" e - As populações Mestiças na Amazônia". Finalmente, em 1887, publicou na Revista Trimestral do Instituto Histórico e Geográfico Brasileiro o estudo — "As Populações indígenas e mestiças da Amazônia: Sua Linguagem, suas crenças e seus costumes- Tapuios e seus descendentes", antes intitulado —.As Raças Cruzadas do Pará", presente em Primeiras Páginas. Todos esses escritos são marcadamente presentes em Scenas da Vida Amazônica, em sua primeira edição de 1886, publicada em Lisboa.
} 
de seu caráter literário ou não. Por isso, apesar da parca recepção, ela é, no entanto, diversificada nas áreas de conhecimento em que se manifestam, assim como nas considerações sobre a obra.

A este respeito, Machado de Assis (1889) afirma que Scenas da Vida Amazônica é uma novela e o autor um miniaturista. Lucia Miguel Pereira (1957) defende que somente "O Crime do Tapuio" é bom [e que, segundo ela, José Veríssimo afirma ser essencialmente real], “A Sorte de Vicentina" é um conto mais longo ou uma curta novela, e os esbocetos são mais intencionalmente literários que os contos, sobretudo, "O Lundum", uma tentativa de poema em prosa.

Ainda sobre a obra, João Alexandre Barbosa (1974, p. 32) diz tratar-se de uma ficção que age como "uma espécie de pequena sociologia". Por sua vez, Alfredo Bosi (2007) afirma que José Veríssimo perpassa do narrador de Cenas da Vida Amazônica ao seco analista dos Estudos e da História da Literatura Brasileira. Já Antônio Dimas (2011, p. 18-21) sustenta a ideia de que a obra referenda, como de costume na época, o ficto através do facto, enquanto Mariana Moreno Castilho (2012, p. 172) assegura tratar-se de um escrito etnográfico, pinturas de um cenário de natureza exuberante, habitada pelos indígenas, pelos tapuios que são representados por José Veríssimo como moles, indolentes e pouco afeitos ao trabalho.

A diversidade de interpretação sobre a obra recai sobre o pluralismo da sua linguagem, sobretudo, a literária, que está sempre aberta a inúmeras interpretações. Mas um leitor modelo, como sugere Umberto Eco, realiza hipóteses interpretativas a partir dos elementos da obra, as quais se confirmam ou se negam à medida que as partes do texto são acrescentadas. Se em Scenas é possível encontrar essa pluralidade, e se o leitor as constata no decorrer das partes, é possível compreender que cada um dos leitores percebe o que dá à luz a própria obra.

É fato que as palavras contidas no ensaio são, por excelência, informativas, que elas surgem tais como originalmente expressas nas falas das personagens, do narrador ou nas descrições que tomam as linhas dos esbocetos. Em contrapartida, a mitopoética tão próxima da criação estética, literária na sua existência e forma, é objetivada no ensaio, nas notas prétextuais, paratextos e desde o título que sugere uma dimensão simbólica não delimitável, pluralística tanto no que pode significar, quanto sobre quem realiza as significações.

Para somar ao campo interpretativo da literatura de Veríssimo, é importante realizar um retorno à obra para discutir se há narratividade e com ela a ficção, já que em sua recepção alguns de seus críticos discordam a este respeito. Considerando o lugar de onde pensa cada leitor, pretende-se aqui refletir sobre essas questões literárias e, dentre elas, sobre a figura 
elementar do narrador, essa entidade que conta, cria a história, cuja memória constrói uma ampla variedade de imagens na obra.

José Veríssimo, o autor, é chamado por Castro (2013) ${ }^{4}$ de o artista plástico da palavra; o narrador de Scenas. Para ele, se têm no livro as duas figuras: aquele que forja a palavra tornando-a estética, conferindo plasticidade à escrita, e o contador que leciona o que vale a pena ser dar a conhecer. Portanto, reconhecem-se no enunciado os dois, autor e narrador, mutuamente existentes e atuando cada um em seu espaço para a feitura do livro, então compreendido como um objeto da arte.

É um observador, como diz Machado de Assis ${ }^{5}$, um paisagista e miniaturista que trás, por estas paisagens de memória, mais do que Sainte-Beuve com sua obra Volupté (1835) o fez. Segundo afirma, é um novelista, antes de atingir o alto grau de crítico literário. Pelo gênero literário percebido pela crítica, pressupõe-se um narrador que reside no entremeio, ponto central da bifurcação entre o tex to literário e o seu oposto.

Pode-se entender em Scenas, que diante da passagem o narrador surge transfigurado, criando mimeses, imagens visuais via palavra, (re)construindo contextos, produzindo imagens reais e de acordo com o mundo de uma ideia conhecida. De outro modo, o autor pertence ao lado distinto da fronteira onde está a realidade por ele interpretada conforme seus elementos e mentalmente construída. É sobre este duelo entre autor e narrador, que mais figura uma colaboração, que se tratará adiante.

\section{O AUTOR NA FRONTEIRA}

O lugar da escrita de José Veríssimo é a Amazônia oitocentista, no período que compreende a passagem do império à primeira república brasileira. Marcada pela observação das idiossincrasias da região, costumes e modos de vida dos seus sujeitos sociais, reflete o espírito de nacionalidade a partir das representações do sistema social e cultural amazônico, com especial atenção para a intensa mestiçagem responsável pela formação dos grupos sociais no Brasil.

Na primeira edição da obra, datada de 1886, mas já escrita desde 1881 conforme indica seu prefácio, o autor preocupa-se em desenvolver uma clara divisão e nela, com destaque, um capítulo introdutório extenso denominado “As Populações indígenas e Mestiças

\footnotetext{
${ }^{4}$ Prefacio da publicação de 2013

${ }^{5}$ Critica da segunda edição publicada no jornal Gazeta de Notícias [1889].
} 
da Amazônia: Suas linhagens, suas crenças e seus costumes", subtitulado "Tapuios e seus descendentes" 6 .

Como o próprio título infere, reflete sobre as condições de uma vasta América na qual se fundiam as diversas raças e gentes do globo. Tal abordagem revela os prenúncios do que hoje se consagrou chamar hibridismo cultural e que, para José Veríssimo, sob o olhar do séc. XIX, estava "em plena realização", conferindo "unidade étnica à humanidade e "nova face às sociedades que hão de viver no futuro" (VERÍSSIMO, 2013 [1886] ).

Com o ensaio, o autor informa a realidade da Amazônia para além e aquém das representações do leitor da época, habituado aos doces romances de folhetim e insciente a respeito da região Amazônica. Sem conhecimento de mundo para saber dessa realidade, tais representações eram mais ilusórias do que reais e Veríssimo parte da introdução da obra para dizer esta realidade incógnita.

\begin{abstract}
Mostrei com a máxima bôa fé e franqueza o que são essas populações, acompanheias desde que appareceram na nossa história até hoje; a outros, aquelles que, talvez sem consciência da dificuldade da empresa, se mettem de hombro com os fenômenos sociaes, cabe a tarefa infinitamente mais ardua, de facultarem-lhes os meios de se desenvolverem progressivamente. Se este trabalho vale alguma cousa, sirvam-se delle no aproveitamento do elemento mestiço- o nosso verdadeiro elemento nacional (VERÍSSIMO, 1887, p. 389).
\end{abstract}

A palavra objetiva do autor estabelece de imediato à fronteira no texto, que não pode ser ultrapassada. Nela não cabem os artifícios próprios da linguagem poética, pois seu conteúdo não foi escrito com outra função que não a de informar o leitor, aquele que Umberto Eco chama de leitor ideal, pois José Veríssimo o idealiza, prepara-o para que, na leitura dos contos e esbocetos, possa compreender as peculiaridades das culturas, das gentes e da Amazônia imitada. É um trabalho que prepara o leitor para a passagem entre a realidade desconhecida e a ficção aceitável.

Segundo Jeanne Marie Gagnebin (2010, p.13), a fronteira "contém e mantém algo, evitando seu transbordar, isto é, define seus limites não só como os contornos de um território, mas também como as limitações do seu domínio”. Portanto, a linguagem sinaliza os domínios do texto e no capítulo introdutório tem-se um autor que lança o leitor no textomundo amazônico. A preocupação em torno da obra não se dá minimamente em torno de sua exposição ideológica, mas aprofunda-se no fazer conhecer a cultura de uma região e de suas gentes, aproximadamente ao trabalho de um etnógrafo que "esteve lá" e que narra a cultura,

\footnotetext{
${ }^{6}$ O capítulo introdutório de Scenas é publicado anteriormente em Primeiras Páginas [1878] sob o título de "As raças Cruzadas do Para", para somente depois, em 1886, figurar como capítulo introdutório de Scenas da Vida Amazônica.
} 
reconhecendo o discurso social, as manifestações culturais, os costumes e as tradições que se encarnam nos sujeitos, revelando a complexidade cultural amazônica historicamente inaudita e marginalizada.

Clifford Geertz (2008, p. 39), ao explorar o inconsciente através das ações do consciente, afirma sobre o homem que "ele próprio se criou". Para ele, a cultura não é um poder, mas o contexto em que esse poder é encenado, como é construído pelos sujeitos que participam deste processo e como o processo, por sua vez, constrói os sujeitos, dialeticamente. Pode-se verificar que a obra é um objeto de conhecimento dessas construções, as quais são traçadas pelo autor com cunho etnográfico.

Assim, a realidade está para o autor como a cultura ao observador, posta para ser interpretada e construída sob a sua perspectiva. Há, neste caso, uma intencionalidade: interpretar o real, uma narratividade histórica que não deixa passar as peculiaridades das raças, o processo de colonização da região, religiosidades, linguagens e trabalhos próprios da cultura amazônica, a popular, como costuma ressaltar o autor.

\section{O NARRADOR NO LIMIAR}

Nos séculos XVIII e XIX, a ideia de autor era influenciada por um biografismo literário. Tal tendência conferia para ele a qualidade de deus, o gênio criador através do qual o leitor deveria submeter-se, desvendando-o para somente assim compreender a sua obra. Entretanto, ainda no séc. XIX, o método biográfico defendido por Saint-Beuve (1804-1869) caracterizado por Marcel Proust (1988, p. 51) pela investigação exausta de dados sobre o autor para a compreensão de sua obra foi contestado por Roland Barthes (1998, p. 65), o qual declara a "morte do Autor" afirmando que "a escritura é a destruição de toda voz, ou toda origem [...] é esse neutro, esse composto, esse oblíquo onde foge o nosso sujeito".

Morto o autor, no sentido de sua super valorização para o entendimento da obra, considerou-se o narrador, sua voz que dá passagem a outros personagens, a entidade através da qual a história passa a ser novamente construída, agora, no campo da ficção e nela compreendida. Este narrador é, portanto, uma figura própria do texto ficcional, sua presença na história ocasiona o despertamento de que o pórtico está adiante, aberto no texto. A constatação de sua presença é a marca singular de que o texto ficcional é existente.

Compreende-se a ficção no sentido etimológico da palavra, fictione como uma construção realizada de uma realidade imaginada. Para Wolfgang Iser (1983, p. 386), "quando a realidade repetida no fingir se transforma em signo, ocorre forçosamente uma transgressão 
de sua determinação correspondente. O ato de fingir é, portanto, uma transgressão de limites" e é nessa transgressão que o imaginário criado se expressa.

Deste modo, entende-se a ficção como uma expressão, o limiar proposto por Benjamin (2012), a construção de um quase-ser de uma realidade também construída. Está entre a vida, lugar do autor, e o "sonho", lugar identitário do narrador, o qual em Scenas da Vida Amazônica assemelha-se a figura do Flâneur, de Charles Baudelaire (2009), um arquétipo da experiência de uma Amazônia em vias de desenvolvimento. Através dele compreende-se a diversidade das culturas, da geografia, dos conflitos políticos, dos resquícios da colonização e dos silenciamentos dos sujeitos em situação de subalternidade. Ele está posto na realidade (re) construída, fantasmagórico, compondo a história ou observando-a, vendo a todos sem por eles ser visto, mantendo o leitor envolto na imaginação, constantemente na passagem.

Assim, mais ficcional é a obra quanto mais ela se afasta do real, ao mesmo tempo em que se configura como um quase-ser, uma realidade trasmutada.

A ficção é produto da imaginação criadora, embora, como toda a arte, suas raízes mergulhem na experiência humana. Mas o que distingue das outras formas de narrativa é que ela é uma transfiguração ou transmutação da realidade, feita pelo espírito do artista, este imprevisível e inesgotável laboratório. A ficção não pretende fornecer um simples retrato da realidade, mas antes criar uma imagem da realidade, uma reinterpretação, uma revisão. É o espetáculo da vida através do olhar interpretativo do artista, a interpretação artística da realidade (COUTINHO, 1976. p.30).

A obra parte, portanto, de uma ideia construída. Nela estão as passagens, os limiares, onde o leitor encontra-se e onde o narrador o coloca. Cada evento surgido demarca a transição que parte da realidade para encontrar na sua recriação o seu lugar de ser, como uma experiência onírica em plena realização. Como explicita Benjamin (2006, p. 535)

Ritos de passagem - assim se denominam no folclore as cerimônias ligadas à morte, ao nascimento, ao casamento, à puberdade etc. Na vida moderna, estas transições tornaram-se cada vez mais irreconhecíveis e difíceis de vivenciar. Tornamo-nos muito pobres em experiências limiares. $\mathrm{O}$ adormecer talvez seja a única delas que nos restou. E, finalmente, tal qual as variações da figura do sono, oscilam também em torno de limiares os altos e baixos da conversação e as mudanças sexuais do amor. "Como agrada ao homem", diz Aragon, "manter-se na soleira da imaginação!” (Paysan de Paris, Paris, 1926, p. 74). Não é apenas dos limiares destas portas fantásticas, mas dos limiares em geral que os amantes, os amigos, adoram sugar forças. As prostitutas, porém, amam os limiares das portas do sonho. - O limiar [Schwelle] deve ser rigorosamente diferenciado da fronteira [Grenze]. O limiar é uma zona. Mudança, transição, fluxo estão contidos na palavra schwellen (inchar, entumescer), e a etimologia não deve negligenciar estes significados. Por outro lado, é necessário determinar o contexto tectônico e cerimonial imediato que deu à palavra o seu significado. Morada do sonho.

Em Scenas, enquanto na primeira parte está o autor fronteiriço, na segunda e terceira está o narrador no limiar, mudando, pois (re)criando a realidade. Iniciando a segunda parte, 
"O Boto" pode compreender primeiramente a passagem da realidade (presente no capítulo introdutório) para a ficção (que compõem os contos e esbocetos). No conto está oníricamente realizado o transbordamento da fronteira que liquidifica a linguagem antes objetiva, dando ao leitor o limiar. O que se encontra neste entremeio é uma alusão a crença amazônica do boto, cujo interior "está cheio de contos maravilhosos sobre esse animal” (VERÍSSIMO, 2013 [1886], p.75). No conto, somente no final há indicativos sobre a tal crença, explicação nada folclórica de que se trata do regatão que engravidou a menina:

Rosinha desde esse tempo começou a emagrecer; de pálida que era tornou-se amarela; ficou feia. Tinha um ar triste de mulher desgraçada. Seu pai notou essa mudança e perguntou à mulher a causa dela. Foi o boto, respondeu D. Feliciana, sem dar outra explicação e sem dizer até aonde tinha ido a ação do peixe sobrenatural [...] nem todos quiseram crer naquela versão [...] (VERÍSSIMO, 2013 [1886], p.170)

O narrador de "O Boto", como de toda a ficção, é uma "aparição única de uma coisa distante, por mais próxima que ela esteja" (BENJAMIN, 2012, p. 108). A realidade criada fica para trás enquanto é recriada por um observador que conta a história pela ação da experiência e que, conforme Benjamin, "gostam de começar sua história com uma descrição das circunstâncias em que foram informados dos fatos que vão contar a seguir" (BENJAMIN, 1994, p. 205).

Assim, o conto inicia-se com a fala: "naquele dia, o sr. Porfiro Espírito Santo recolheu-se para jantar mais cedo, de mau humor, a catadura fechada, sem falar a ninguém" (VERÍSSIMO, 2013 [1886], p.120). A expressão "Naquele dia" funciona como uma roupagem de "Era uma vez", que inicia os contos clássicos e fábulas. Com ela o narrador marca sua presença na história, contando o cotidiano da personagem de quem é testemunha. $\mathrm{O}$ mesmo ocorre quando introduz o conto "O Crime do Tapuio": "Mal completara Benedita os sete anos, quando os pais, uns pobres caboclos de Trombetas, deram-na ao Felipe Arauacu" (VERÍSSIMO, 2013 [1886], p.171) ou quando em "A Sorte de Vicentina" realiza descrições para seguir a apresentação das personagens.

Embora haja uma referência histórica, a menina, José Tapuio e Vicentina existem no limiar, o quase-ser real que dá conta o narrador observador. Já no conto o "Voluntário da Pátria", eles, autor e narrador chegam a quase tocar-se na passagem a ponto de se perguntar se este conto é mesmo uma ficção, pois no pré-texto da edição de 1886, o autor transgride a fronteira estruturante do livro, mas não alcança o limiar. Ou seja, sai do capítulo de cunho etnográfico que inicia a obra para introduzir o conto: 
[...] como um protesto de consciência que se não dobra, nem à opinião das maiorias, nem tão pouco aos fatos consumados, consagro à memória desses inconscientes heróis este nobre conto, cuja ironia, quase escuso dizê-lo é para eles uma sincera lembrança de piedade (VERÍSSIMO, 2013 [1886], p. 198).

No entanto, ele respeita o limite, cria um lugar para contar a história real, mas não chega ao entre-lugar que é por excelência do narrador que inicia o conto: "quando começou a guerra do Paraguai, em um pequeno sítio de paraná-mirim de Vila Bela, viviam uma velha de nome Zeferina, seu filho Quirino, rapagão de trinta anos, bem constituído, e sua neta Maria, de dez [...]” (VERÍSSIMO, 2013 [1886], p.198).

Em “O Voluntário da Pátria”, o autor começa no pré-texto, mas o narrador rememora no início do conto e encerra a narrativa enfatizado: -"Aí tem o senhor-concluir a pessoa que me contou esta história- com se arranjaram voluntários da pátria” [...] (VERÍSSIMO, 2013 [1886], p.198).Trata-se de um tipo de narrador que Genett (2008) denomina extradiegético, que diz respeito a um segundo narrador que surge no final do conto e conta a história dos voluntários a partir de uma perspectiva diferente, como se a história fizesse parte da memória de uma coletividade.

Como diz Benjamin, "a experiência que passa de pessoa a pessoa é a fonte a que recorreram todos os narradores" (BENJAMIN, 1994, p. 198). O que postula o filósofo alemão se dá em todos os quatro contos da obra literária de José Veríssimo, ainda que tenha nela partes próprias do autor e que estas partes se aproximem dos textos narrativos.

Uma peculiaridade de Scenas, suas tipologias textuais, permite até mesmo compreendê-la com base no que Josefine Ludmer (2007) considera como a inexistência entre realidade e ficção, o que denomina "literatura pós-autônoma”. A propósito,

\footnotetext{
As literaturas pós-autônomas (essas práticas literárias territoriais do cotidiano) se fundariam em dois (repetidos, evidentes) postulados sobre o mundo de hoje. O primeiro é que todo o cultural (e literário) é econômico e todo o econômico é cultural (e literário). E o segundo postulado dessas escrituras seria que a realidade (se pensada a partir os meios que a constituiriam constantemente) é ficção e que a ficção é a realidade (LUDMER, 2007, p. 2).
}

Scenas da Vida Amazônica, portanto, experimenta o trânsito que se faz do autor para o narrador, do real para o ficcional e do ficcional para novos "índices de realidade" e "índices de ficção". Daí, se pode pensar que a figura do narrador é sine qua para contar as histórias que sua imaginação experiente busca representar, o que interessa neste artigo discutir, e que sua aparição, dentre os outros elementos indispensáveis à narratividade (tempo, personagens, espaço e seus desdobramentos), colabora para o entendimento da constituição da obra literária. 
O narrador, entidade do limiar, figura com maior ou menor relevância nos contos e esbocetos e é ele que permanece na obra, quando na segunda edição de Scenas, José Veríssimo retire o capítulo e textos introdutórios presentes na primeira edição (1886) e decide: o autor sairá. A partir da segunda edição, datada de 1889, a obra figura-se inteiramente literária, permanecendo aquelas narrativas recriadas que o capítulo introdutório dedicou-se a explicar.

\section{EVENTOS EM SCENAS}

Até o presente momento, discorreu-se sobre o narrador como a figura sine qua non da ficção, aqui interpretada como o limiar, o quase-ser da realidade. O narrador é, portanto, uma figura central do texto narrativo ficcional. Por isso, considera-se importante compreender o estatuto desse texto, a saber, o evento como categoria das mudanças de estado anunciada, seguindo o proposto pelas mais recentes discussões no campo narratológico, como a realizada por Wolfgang Schmid, com a obra Narratology: an introduction (2010).

Segundo Walter Benjamin (1985), uma narrativa não se efetiva no tédio, “o pássaro de sonho que choca os ovos da experiência" (BENJAMIN, 1985:204). Parte-se desta ideia do filósofo para enfocar dois pontos: o primeiro diz respeito à importância de se vencer a monotonia que por ventura a narrativa possa apresentar. O segundo, para retomar seu pensamento de que "a experiência é a fonte a que recorrem todos os narradores". Estes dois pontos são elementares para a existência da narrativa e, consequentemente, para o narrador. Portanto, a novidade, relativa ao texto, e a experiência, ao narrador, levam à máxima de Wolf Schimid (2010, p. 12) de que uma história não se constitua alheia ao evento: "uma ocorrência particular, algo não pertencente ao cotidiano" (Schmid, 2010, p. 12).

Conforme Schimid (2010), o evento é considerado como categoria da narrativa desde a renascença e é na novela, mais propriamente que foi apresentado. Para ele, é o historiador cultural russo Jurii Lotman [1922-1993] que primeiro define o evento de maneira sistemática: "Um evento é [...] sempre uma violação proibida, um factum que houve realização, embora não devesse ter ocorrido" (LOTMAN, 1970, p. 286).

O que ele chama de Sujet, caracteriza-se como uma sequência de acontecimentos eventuais que se dão a partir de alguns quesitos: O campo semântico de dois conjuntos que se complementam e intransponibilidade destes conjuntos. Entretanto, neste caso, o agente da ação da narrativa consegue superá-la, formando o texto sujet. Chama atenção que para Lotman (1970), o sujet é uma transgressão da fronteira, são textos revolucionários por sua 
natureza transformadora. Por isso, dá uma nova definição de vento, o qual é a transgressão da fronteira proibida, a qual está determinada pela estrutura do texto "sem sujet". Para ele, uma movimentação do herói atribuída ao espaço indicado não é evento (LOTMAN, 1970, 288).

Por sua vez, Wolf Schmid (2010) leva em conta que o evento deve ser tratado para além da compreensão de Lotman. Para ele, o evento não é uma violação da norma, "também não implica necessariamente um desvio da ordem dada no mundo narrado, cujo cumprimento mantém a ordem deste. A fronteira não precisa significar uma proibição" (Schmid, 2010, p.13). Neste caso, a fronteira sem proibição aproxima-se do entendimento de limiar, ela não é um limite, é uma passagem, como postula Walter Benjamin (2012). Relacionado ao entendimento de Schmid, nesta passagem podem se entremear a exegese, onde estão as metanarrativas do narrador, e a diegese da história narrada, a qual se dá quando o narrador reavalia a ação dos protagonistas ou quando deixa claro seu entendimento do contexto a partir da sua própria narração.

Para Schmid (2010, p. 16-19), o evento diz respeito, necessariamente, à mudança e sua resultatividade. Portanto, precisa compor-se de: 1- Relevância: o resultado precisa ser relevante e não trivial na narrativa. Se não há relevância, definitivamente não se trata de uma experiência, a fonte a que recorrem todos os narradores, o que é um problema para a existência da narrativa; 2- Imprevisibilidade: aqui fica claro a diferenciação existente entre a teoria de Schmid (2010) e a de Lotman (1970). Nesse caso, o evento não é somente a ultrapassagem da fronteira proibida, mas a quebra de uma expectativa, do script; 3Consecutividade: o evento se eleva a partir do momento em que as próprias mudanças interferem e mudam o pensamento e ações dos sujeitos; 4- Irreversibilidade: por conta da mudança, não é possível voltar ao estado anterior; e 5- Não-interatividade: mudanças que se repetem, representam um baixo nível de eventualidade que apenas parecem ser um evento.

Destes, a relevância e a imprevisibilidade mais propriamente fazem o evento. São assim compreendidas a partir da interpretação do contexto, o qual pode significar tanto o sistema de normas sociais gerais, específicas ao tempo vigentes do autor, quanto as normas sociais individuais das entidades de uma narrativa. Em Scenas da Vida Amazônica, há presença dessas duas composições: relevância e imprevisibilidade, embora não sejam recorrentes ou repitam-se em uma mesma narrativa.

No conto "O Boto", Rosinha sai para o quintal e é envolvida sexualmente por Antônio, exatamente no momento que a natureza, cão, pássaros, lua e insetos dão presságios de agouros. A partir deste momento a narrativa muda, o destino da família também. Ocorre, então, a irreversibilidade, pois os personagens não conseguem retornar ao ponto de partida da 
mesma maneira, toda ação caminha para a desgraça da menina que a princípio parecia ser realmente bem quista por Antônio, mas depois é abandonada sem piedade, grávida, desonrada, tendo que viver na narrativa a desculpa de que carrega um filho do boto lendário (VERÍSSIMO, 2013, p. 75).

No conto o "O Crime do Tapuio", o evento acontece quando José aparece para roubar Benedita dos maus tratos constantes que sofria nas mãos de Bertrana. O rapto da menina quebra uma expectativa, pois o leitor não espera que José, em sua tímida aparição, o faça. Já o julgamento de José e sua condenação, mesmo com o retorno de Benedita, indicam a irreversibilidade do evento ocorrido (VERÍSSIMO, 2013, p. 75), pois ainda que as provas indiquem que ele não matou Benedita, é condenado tanto no tribunal quanto na vida, morto por uma bala, com um destino confirmado pelo "lobo histórico", em alusão a máxima do filósofo inglês Thomas Hobbes: "o homem é o lobo do homem".

Em "O Voluntário da Pátria”, a relevância do evento é marcada pela chegada de Chico Cabano para prender Quirino. Sua prisão muda o contexto da narrativa. Da vida pacata em Vila Bela ao embarque revoltoso para a guerra do Paraguai, do cotidiano de Zeferina no sítio de paranamirim para a peregrinação nos palácios da capital, tudo muda na vida dos personagens que passam a sofrer desde então. Entretanto, as repetições das ações são representativas da não-interatividade que apresentam baixo nível de eventualidade.

Em “A Sorte de Vicentina”, após a primeira parte deter-se a descrever a geografia do lugar e a segunda iniciar a descrição dos conflitos sociais que se arrastam a tempos entre os portenses e os moradores da Vila, ao final o narrador apresenta a primeira mudança que se dá na sorte de Vicentina. O taberneiro casa-se com a mãe da menina e logo depois morre picado por uma arraia. Seu óbito legou uma fortuna para Vicentina, causa das disputas pela sua tutoria e nesta disputa outra entre os grupos políticos da cidade. Vicentina é guardada, depois estuprada, depois casa com um vaqueiro alcoólatra e violento, tem uma filha, a criança é comida por uma onça, até finalmente tornar-se prostituta.

O primeiro evento (a morte do padrasto e o recebimento da herança) é relevante, pois muda sobremaneira o destino de Vicentina, está para a imprevisibilidade, pois a morte do taberneiro surpreende e ocasiona cada uma das reviravoltas na sorte da menina. Entretanto, considerando-se o todo da narrativa, os sucessivos eventos se baseiam na não-interatividade, pois suas repetições tornam-se irrelevantes, eles não mudam os rumos da história nem o destino de Vicentina, apenas acontecem em gradação para fixar a total desgraça de sua vida e o determinismo social a que está submetida. 
Quanto ao contexto mencionado anteriormente, não é preciso ter vivido no séc. XIX para compreender este tempo representado em Scenas da Vida Amazônica. O contexto se revela ao leitor atual, aquele anunciado por Machado de Assis em sua crítica (1889), quando, por exemplo, o evolucionismo de Charles Darwin é aparente na descrição da tapuia que levava uma "vida anfíbia", no determinismo de Spencer quando o mestiço é um herói na floresta enquanto no tribunal é uma fera e do positivismo de Comte quando um casal de tapuios muda para cidade a fim de se tornarem "civilizados".

Nos Esbocetos, porém, há modificações que devem ser consideradas. São esboços de narrativas, é o primeiro ponto. Como se espera, narram uma representação da realidade, mas no primeiro deles, "O Serão", a descrição é preponderante. Para Genett (2008), ainda que de maneira tênue, narrativa e descrição se diferem, há uma fronteira entre elas e a predominância da descritividade chama atenção para análise da parte que cabe à narrativa, se há narrativa.

No esboceto, a fronteira entre a descrição e narrativa só é transgredida pelo narrador que, após longa ambientação e apresentação das personagens, efetiva-se como tal por tomar, mesmo que parcamente, o ponto de vista da personagem. Além desta momentânea figura do narrador, marcando a passagem para a ficção, o esboceto não apresenta nenhum evento. Portanto, segundo Schmid (2010), o esboceto não se configuraria necessariamente uma narrativa, por faltar-lhes eventos e com eles mudanças com resultatividades.

No esboceto "A Lavadeira", tem-se um narrador personagem, que conta a visão de uma mulher a banhar-se na beira do rio. Ao cabo da sétima parte, o narrador inicia uma rememoração. Neste ponto, os encantos da Iara das águas amazônicas integra a narrativa na memória do narrador, até que a poética lenda dos filhos de Manaus é interrompida quando o avista uma sucuriju prestes a morder o rosto da mulher. A visão da cobra, entretanto, não confere mudanças à narrativa. $\mathrm{O}$ narrador a mata, volta para a cidade e a mulher casa-se com um regatão, mas não se trata de um evento justamente por não haver nele relevância.

Em "O Lundum” ocorre o mesmo. A descrição da sala, da orquestra e das músicas tocadas é superada pela narração da entrada de uma mulher que surge na arena. Preparada para o lundum, disse: -Lá!!!... Ninguem?!..., (VERÍSSIMO, 2013, p. 187) como a desafiar os homens presentes na festa. Daí em diante o que se segue é a dança entre ela e o rapaz que aceitou o desafio, os olhares arrufados das outras mulheres e o cansaço dos músicos diante da alegria incontrolável da dançarina. Por isso, param de tocar, ela deita-se na rede e o narrador declara que aquele foi seu último ludum antes do casamento com um vaqueiro e seu desaparecimento das festas do Divino. Como se observa, não há evento e nada acontece ou se transforma como seu resultado. 
No esboceto "Indo para a Seringa", o narrador se manifesta no quarto momento, quando se põe a contar a história do velho e sua família em um momento de silêncio e sossego. O barulho da canoa no rio, porém, quebra essa expectativa e a chegada do regatão torna-se um evento, pois após ele a rotina da família muda. Eles não possuem condições financeiras para irem à seringa, mas vão financiados pelo comerciante. Viajam com a expectativa recém-despertada de possível enriquecimento. Entretanto, a narrativa encontra seu desdobramento somente no próximo esboceto, "Voltando da Seringa", como se eles fossem complementares.

De fato, há imprevisibilidade com a quebra de expectativa em "Indo para a Seringa", como há também consecutividade a partir da mudança da ação dos personagens. Em "Voltando da Seringa" novamente é a chegada do regatão que realiza o evento, tomado ao modo da irreversibilidade. Os personagens, após passarem pela decepção do fim da borracha, dos abusos das filhas e das dívidas com o regatão, não consegue voltar ao seu estado anterior, de sossego, pois o que os esperam é a dor, a miséria e a desonra (VERÍSSIMO, 2013, p. 208).

No último dos esbocetos, "A Mameluca", o autor da fronteira ressurge, traz a voz de outro, o Baena que em 1833 descreveu as características físicas e os modos de trajar da mameluca. Neste esboceto não há evento, como também não há um narrador. Trata-se de uma descrição. É como se o autor da fronteira desse um passo adiante no limiar, mas não transgredisse o limite. Permanece ali, desenvolvendo uma prosa poética com ares de etnografia.

\section{CONSIDERAÇÕES FINAIS}

Neste artigo, buscou-se compreender, à luz da teoria de Walter Benjamim (2007) como uma obra pode configurar-se no campo da literatura. Neste intento, envolveram-se questões acerca da realidade, da ficção, do narrador como figura importante da passagem entre os dois campos, da narratologia e sobre o evento como condição basilar para o texto narrativo literário, como postula o pensamento de Wolfgang Schmid (2010).

Em analogia a teoria de Benjamin (2007), interpretou-se a realidade pertencente ao campo da fronteira enquanto a ficção aos campos limiares. Neste sentido, compreendeu-se que é ficção a escrita que atua no lugar da passagem, o quase-ser real sem contudo estar a ele obediente. Portanto, não é ficção aquela que permanece limitada à realidade, sem poder transgredi-la, pois a ficção é a própria transgressão que caminha da interpretação [construção] à representação [reconstrução] da realidade. 
Daí, a ideia de limiar é cabível para o entendimento da referência literária deste artigo, Scenas da Vida Amazônica (1886), por ela ultrapassar a fronteira do que é e não é literatura. Para essa teorização, as discussões de Josefina Ludmer (2007) foram relevantes por, ao tratar do conceito de literatura pós-autônoma, pensar a obra para além da proibição. Portanto, Scenas da Vida Amazônica (1886) caminha em uma linha tênue entre o que é realidade e o que é ficção. Ela não está presa em uma tipologia, pois quando real apoia-se na figura do etnógrafo ou ensaísta e, quando ficcional, sustenta seu estatuto nos elementos próprios do texto narrativo.

Pela diversidade textual da obra que apresenta um extenso capítulo ensaístico e outros dois literários, a fronteira (ensaio) e o limiar (ficção) não apenas colocam-se em um campo de limite estabelecido, a priori proibidos de quaisquer contatos, como permitem a visitação de seus agentes formuladores: ora o autor adentra o espaço estrutural da "ficção" (mas logo sai), ora o narrador visita o campo da "realidade", livre para transitar entre os dois campos, na narrativa mais propriamente.

$\mathrm{Na}$ obra, são partícipes da fronteira o primeiro capítulo, os pré-textos, os paratextos e pertencem ao limiar os contos e esbocetos. O primeiro capítulo presente na edição de 1886 é de propriedade do autor, a expressão da realidade amazônica por ele construída. Tal construção, como assinala Clifford Geertz (1989), de certo modo constitui uma ficção, não ao modo das que se constroem com afinco na linguagem e com a incorporação de elementos próprios da narrativa, mas como uma construção interpretativa da realidade. Assim, o ensaio de cunho etnográfico é o lugar para os acontecimentos produzidos pelo homem/autor em torno da mestiçagem, da pós-colonização e da cultura popular como resultado das relações de poder.

Sobre a narrativa ficcional, compreendeu-se que ela é um espaço para o evento Schmid (2010), construído pelo narrador nas representações dos mesmos acontecimentos. O narrador configura-se, portanto, como uma entidade, está em Scenas como Flâneur, tal como o compreendido por Benjamin (2007), uma figura fantasmagórica que pertence por excelência ao campo da reconstrução, mas com poder para atravessar as fronteiras do texto construído.

Entende-se que ele realiza, por assim dizer, uma interpretação da história, configurando a ficcionalidade, como uma imagem refletida no espelho que parece real, mas é na verdade um pseudocontexto. O narrador/ Flâneur, vive uma realidade ilusória, que é a sua maneira própria de narrar e que leva o leitor para a narrativa literária. Na obra, ele conta a história, ao mesmo tempo em que é competente para, na sua descrição e ambientação, rememorar a realidade. 
Não é por acaso que nos contos da obra hajam falas idênticas aos escritos de cunhos etnográficos, funcionando como uma retomada de um estado da consciência. Não obstante, em suas lembranças do passado e observações do presente está a capacidade mimética que o distancia da realidade, ao mesmo tempo em que o aproxima dela, via representação, dialeticamente. Assim, há um transitar entre história e literatura, cujas passagens cabem ao narrador promover e à narratibilidade ao evento sustentar.

As ideias de Walter Benjamin (2012) e os estudos de Wolf Schmid (2010) foram importantes para o entendimento de que o autor, narrador histórico, constrói a realidade; o narrador literário a reconstrói. Ele rompe a fronteira e a recomeça sob um diferenciado ponto de vista, perspectiva, foco, presença ou ausência no discurso. Daí considera-se que a narrativa histórica e a narrativa literária existem próximas ao intervalo e que somente o narrador, como uma entidade privativa e sui generis do texto literário, pode prenunciar, justificado reflexivamente pelos eventos, o limiar em Scenas da Vida Amazônica: uma obra de passagens.

\section{REFERÊNCIAS}

BENJAMIN, Walter. Charles Baudelaire: um lírico no auge do capitalismo. Obras escolhidas III. São Paulo: Brasiliense, 1991. BENJAMIN, Walter. Magia e técnica, arte e política: ensaios sobre literatura e história da cultura. São Paulo: Brasiliense, 2012a.

Escolhidas, 1).

Magia e técnica, arte e política. 7. ed. São Paulo: Brasiliense, 1994. (Obras

O Narrador- Considerações sobre a obra de Nikolai Leskov. In: Obras Escolhidas: Magia, Técnica, Arte e Política. São Paulo: Brasiliense, 1985.

Passagens. Belo Horizonte: Editora UFMG, 2006

BLOOM, Harold. O Cânone Ocidental: Os livros e a escola do tempo. Trad. SANTARRITA, Marcos. Rio de Janeiro: Objetiva, 1995.

BOURDIEU, Pierre. A economia das trocas simbólicas. São Paulo, Perspectiva. 1982

COUTINHO, Afrânio. Notas de Teoria Literária. Civilização Brasileira,1976. p.30

DANZIGER, Marlies K. e JOHNSON, W. Stacy, Introdução ao Estudo Crítico da Literatura, São Paulo, Cultrix, 1974

ECO, Umberto. Lector in fabula. São Paulo: Perspectiva, 1988. 
GAGNEBIN, Jeanne Marie. "Entre a vida e a morte". In Otte Georg, Seldmayer Sabrina e Cornelsen Elcio (org) Limiares e passagens em Walter Benjamin. Belo Horizonte, Editora UFMG, 2010.

GEERTZ, Clifford. A interpretação das culturas. Rio de Janeiro: Guanabara Koogan, 1989.

GENETTE, Gérard. Fronteiras da narrativa. In: Análise Estrutural da narrativa. Tradução: Maria Zélia Barbosa. $5^{\text {a }}$ edição. Rio de Janeiro: Editora Vozes, 2008.

ISER, Wolfgang. Os atos de fingir ou o que é fictício no texto ficcional. In: COSTA LIMA, Luiz. Teoria da Literatura em suas fontes. V. II. $2^{\text {a }}$. ed. Rio de Janeiro: Francisco Alves, 1983.

LUDMER, Josefina. Literaturas-Pós-Autônomas. In. Ciberletras - Revista de crítica literaria y de cultura, n. 17, julho de 2007. Disponível em: <http://culturaebarbarie.org/sopro/n20.pdf>. Acesso em: 22 set 2017

SCHMID, Wolfgang. Narratology: an introduction. Berlin/New York: Gruyter, 2010.

TODOROV, Tzvetan, Os Géneros do Discurso, Lisboa, Edições 70, 1978 